\title{
DISTRIBUTION OF THE CLOVER ROOT WEEVIL BIOCONTROL AGENT IN THE NORTH ISLAND OF NEW ZEALAND
}

\author{
P.J. GERARD, T.M. EDEN, D.J. WILSON and G. BURCH \\ AgResearch, Ruakura Research Centre, Private Bag 3123, Hamilton, \\ New Zealand
}

Corresponding author: pip.gerard@agresearch.co.nz

\begin{abstract}
The Irish wasp Microctonus aethiopoides was released in 2006 as a biocontrol agent for the clover root weevil Sitona lepidus, a serious pest of white clover in New Zealand. Following successful establishment, two strategies were implemented to accelerate the widespread establishment of the parasitoid throughout the North Island. The first approach was the establishment of regional nursery sites that act as point sources for natural and assisted dispersal. With the assistance of Regional Councils and major landowners, these were set up at sites favourable to the wasp, and local people were provided the training and support to undertake collections and distribution of parasitized weevils. Secondly, samples of parasitized weevils were distributed for release directly to farmers through pastoral industry networks and events. Initial results indicate that while the parasitoid established rapidly at Taranaki and Waikato nursery sites as anticipated, it has failed to establish in Northland in two successive seasons.

Keywords: Microctonus aethiopoides, Sitona lepidus, biocontrol, parasitoid releases.
\end{abstract}

\section{INTRODUCTION}

Since its discovery in 1996 (Barratt et al. 1996) the clover root weevil (Sitona lepidus Gyllenhal) has become one of New Zealand's worst white clover pests (Eerens et al. 2005). Following ERMA approval in November 2005, the biocontrol agent Irish Microctonus aethiopoides Loan was released in early 2006 at experimental sites in Waikato, Hawke's Bay and Manawatu (two sites)(Gerard et al. 2007). This parasitoid attacks adult weevils, rendering females sterile almost immediately and killing the host when the parasitoid larva emerges to pupate.

Irish M. aethiopoides established rapidly and with parasitism levels of $13-33 \%$ at the release sites within 6 months, further successful releases were carried out in summer 2006/07 (Gerard et al. 2007). With the parasitoid showing excellent persistence under different pasture management systems, even when host adult generations did not overlap (Gerard et al. 2007), a strategy to ensure the widespread distribution of Irish $M$. aethiopoides in New Zealand was initiated. Key consideration was the size and location of releases. This paper describes the main distribution activities undertaken in the North Island during 2007/2008 summer, and the rationale behind the strategy adopted.

\section{METHODS}

The AgResearch biocontrol team at Ruakura has adopted a dual approach of medium (nursery sites) and very small releases to individual farmers (referred to as giveaways) as the North Island distribution strategy. All releases used parasitoids mass reared in the laboratory using field-collected S. lepidus adults and exposure rate of two parasitoids/100 weevils for a minimum of 6 days. Parasitism levels using this technique at Ruakura are typically $40-80 \%$ (P.J. Gerard et al., unpubl. data). 


\section{Field nursery sites}

Nursery sites are locations where natural enemies are released to reproduce within an existing pest infestation and then are collected for subsequent distribution (Van Driesche 1993). They reduce the requirement for a large mass-rearing programme and associated demand on facilities and staff time. Several organisations were keen to participate in this scheme and the AgResearch biocontrol team set up their own site at Ruakura (Table 1). Easily-accessible sites were sought that had good, relatively stable white clover and weevil populations, conditions that facilitate long term Irish M. aethiopoides populations. While the concept of nursery sites offers self-perpetuating sources of parasitized weevils for natural and assisted dispersal as long as required, they are relatively expensive to set up (approximately $\$ 10,000$ each) and local people are needed in most regions to undertake collections for monitoring and distributions.

The releases used for the nursery sites comprised of 1000-2500 S. lepidus parasitized with Irish $M$. aethiopoides from at least two breeding lines originating from different geographic localities in Ireland. To spread risk, the releases in the 2007/08 season were split between sites and months. Subsamples of the weevils to be released in December 2006 were frozen and dissected to determine parasitism levels.

TABLE 1: North Island nursery site releases of $S$. lepidus adults parasitized by Irish M. aethiopoides: December 2006-January 2008.

\begin{tabular}{lcccc}
\hline Operator & Location & $\begin{array}{c}\text { Parasitized CRW } \\
\text { released }\end{array}$ & $\begin{array}{c}\text { Month of } \\
\text { release }\end{array}$ & $\begin{array}{c}\text { Establishment } \\
\text { (\% parasitism) }\end{array}$ \\
\hline $\begin{array}{l}\text { Taranaki Regional } \\
\text { Council }\end{array}$ & $\begin{array}{c}\text { Stratford } \\
\text { Lepperton }\end{array}$ & 2500 & Dec 2006 & Feb 2007 (6\%) \\
Northland & Okaihau & 5000 & Dec 2006 & Not established \\
Regional Council & Okaihau & $700^{1}$ & Dec 2007 & Not established \\
& Pakaraka & $500^{1}$ & Dec 2007 & Not established \\
& Kerikeri & 2000 & Jan 2008 & Not established \\
Landcorp Ltd & Te Kuiti & $1000^{1}$ & Jan 2008 & May 2008 (3\%) \\
& Moutoa & $1500^{1}$ & Jan 2008 & Unknown to date \\
& Ruakura & 3000 & Jan 2007 & April 2007 (5\%) \\
AgResearch & Morrinsville & 1000 & Feb 2007 & April 2008 (24\%) \\
\hline
\end{tabular}

${ }^{1}$ Size of initial release with ongoing releases in 2008.

${ }^{2}$ CRW sample very small (May $2008 \mathrm{~N}=11$ ).

\section{Distribution of parasitoids to individual farmers (giveaways)}

The project whereby parasitized weevils were given out gratis to farmers was designed for multiple purposes. Following widespread media publicity on the parasitoid releases, there was strong pressure from farmers keen to obtain the parasitoid with many having a high awareness of the damage caused by S. lepidus through their own on-farm experiences and research extension. Therefore, the distribution of the $M$. aethiopoides giveaways was a rapid method to deliver the biocontrol agent to those farms most impacted by S. lepidus. Secondly, the biocontrol programme had been funded by farmer levies through DairyNZ and Meat \& Wool NZ, so there was a strong expectation of delivery by farmers. Thirdly, it had an extension component with all giveaways accompanied with an information sheet on the weevil and parasitoid, as well as tips to maintain good clover levels in pasture. It also potentially served to accelerate the rapid widespread dispersal of the Irish wasp through all the North Island and thus hasten the benefits of biocontrol coming on-line. 
The giveaways consisted of $10 \mathrm{~S}$. lepidus adults, that had been exposed to progeny of either a single Irish breeding line obtained from laboratory culture or from parasitoids reared from field-collected weevils from the successful experimental release sites (Gerard et al.2007). The parasitized weevils were placed into $70 \mathrm{ml}$ specimen vials in batches of 10 with a small segment of damp cotton wool and a clover leaf. Distribution was primarily through field days and the DairyNZ and Meat \& Wool NZ networks. Consulting officers and industry contacts were couriered overnight prearranged numbers of vials packed in 4.5 litre polystyrene containers with icepacks. The vials were distributed personally to farmers, along with instructions for release, and an information sheet on the S. lepidus problem and the biocontrol agent. Usually only one vial was provided per farm. However, multiple vials were given to landholders with extensive areas of land or in return for active support of the S. lepidus management programme. Records have been kept of the farms where the parasitized weevils were to be released so districts with low coverage can be targeted for future releases.

\section{Field nursery sites}

\section{RESULTS}

Dissections of subsamples taken from cages used for December 2006 nursery releases showed around $40 \%$ of exposed weevils were parasitized. However, most cages had been exposed to parasitoids for around a week and parasitoid eggs are difficult to detect so was potentially an underestimate. A much higher level of parasitism could be inferred from the female S. lepidus recorded as non-parasitized, of which almost $90 \%$ showed physiological changes in their reproductive organs and fat bodies consistent with parasitism (P.J. Gerard et al., unpubl. data).

Success has been mixed to date (May 2008). Establishment was rapid at the Taranaki and Ruakura sites with parasitism levels ranging between 23 and $64 \%$ by early winter but the widespread North Island drought in summer and early autumn 2008 severely handicapped the planned collection and redistribution activities. The Ruakura and Lepperton S. lepidus populations were too low $\left(<8 / \mathrm{m}^{2}\right)$ to carry out any collections and the widespread lack of white clover combined with very low densities of resident $S$. lepidus on drought-affected farms meant that the probability of establishing the parasitoid was very poor. However, a couple of collections were taken from the Stratford site and distributed to farms in localities that had received adequate moisture.

No parasitized weevils were recovered following the initial 2006 release in Northland in spite of seemingly good conditions for establishment. Further releases were made at the original and two additional sites in December 2007 and January 2008, and again Irish $M$. aethiopoides has not established (Table 1).

\section{Distribution of parasitoids to individual farmers}

Table 2 shows the pattern of distribution of parasitoids to individual farmers according to Regional Council boundaries. In 2007, farmers received giveaway vials from researchers at field days at Dargaville (Northland Regional Council), Limestone Downs (C. Alma Baker Trust) near Port Waikato, and Gordonton near Hamilton (NZ Clover Root Weevil Action Group). In 2008, almost all giveaways went out through the pastoral industry networks, in particular the DairyNZ consulting officers.

The parasitoid distribution project in 2008 was hampered by the widespread drought in the North Island. Sitona lepidus adults for the mass rearing were collected from a Wairarapa clover seed crop as insufficient were available in Waikato. Local knowledge of consulting officers was crucial in identifying districts and farms with adequate clover to sustain S. lepidus populations. As a consequence, over $30 \%$ of the giveaways in 2008 went to Northland farmers, even though this region had over 150 giveaways in 2007 and mass releases at several proposed nursery sites. 
TABLE 2: Regional distribution of giveaway vials of parasitized S. lepidus in 2007/2008.

\begin{tabular}{lcc}
\hline Regional Council & 2007 & 2008 \\
\hline Northland & 157 & 167 \\
Auckland & 35 & 46 \\
Waikato & 46 & 73 \\
Bay of Plenty & 1 & 17 \\
Gisborne & 1 & 0 \\
Hawke's Bay & 1 & 12 \\
Taranaki & 1 & 58 \\
Manawatu & 4 & 140 \\
Wellington & 1 & 29 \\
Total & 247 & 542 \\
\hline
\end{tabular}

\section{DISCUSSION}

The Northland December 2006 release at the proposed Okaihau nursery site inland from Kerikeri appears to have been the first release of Irish $M$. aethiopoides that has failed to establish. This was unexpected; especially as 5000 parasitized S. lepidus had been released. Successful establishment with smaller releases had been achieved that summer at the Taranaki $(n=2500)$ and Ruakura $(n=3000)$ nursery sites and just 1000 parasitized weevils at a farm near Morrinsville in February (Table 1). One possible explanation for the failure was that high temperatures reached in pastures on soils containing iron aggregates, such as at the Okaihau site, were lethal to the parasitoid. Ferguson et al. (2008) showed that $M$. aethiopoides tends to pupate in the top $1 \mathrm{~cm}$ of soil/litter and this may make them vulnerable to extreme temperatures. However, maximum grass temperatures near Kerikeri were not unusually high $\left(23-32^{\circ} \mathrm{C}\right)$ during the time when most released parasitoids would have been pupating (1-7 January 2007) (B. Cooper, pers. comm.). Nevertheless, as a precaution the follow-up releases in Northland were split over several dates and a range of sites. Once again, no evidence of parasitism was found in weevils collected and dissected in May 2008 at any of the sites, even though S. lepidus was abundant and Northland had good rainfall during the summer.

The apparent failure of Irish M. aethiopoides in Northland contrasts with the rapid establishment of Microctonus hyperodae Loan in 1991 when released at Wellsford (Goldson et al. 1994) and further investigations are warranted. The Irish M. aethiopoides persisted well at Waikato sites during the 2007/08 drought with autumn parasitism levels well above 90\% (P.J. Gerard, unpubl. data). With severe soil moisture deficits $(>130 \mathrm{~mm})$ and record high mean daily temperatures in January (e.g. $26.7^{\circ} \mathrm{C}$ at Ruakura, well above that of $24.7^{\circ} \mathrm{C}$ for Whangarei) (National Climate Base data), it seems unlikely that high temperatures alone are responsible for the failure of the parasitoid to establish in the Far North

The distribution of 10 parasitized weevils to farmers, as well as expediting the potential dispersal of the parasitoid, was an opportunity to highlight the value of close links between key primary industries and science. Rarely can science deliver a research-driven solution to a significant problem directly from the laboratory into the hands of multiple individual farmers. Interactions between industry extension personnel and researchers were critical to project success. Not only did the industry personnel have extensive farmer contacts, the local knowledge they possessed meant they were able to identify 
farms that were still suitable as release sites, at a time when drought was affecting many North Island districts. Furthermore, as the organisations responsible for investing farmer levies, DairyNZ and Meat \& Wool NZ were clearly acknowledged on packaging and accompanying information and publicity.

The gratis distribution of parasitoids to individual farmers contrasts markedly with the strategy used for the commercial distribution of $M$. hyperodae for the biocontrol of the Argentine stem weevil Listronotus bonariensis (Kuschel) when 10,000 parasitized weevils was selected as the minimum number for a release ( $\mathrm{McNeill}$ et al. 2002). However, apart from the extension and promotional aspects intrinsic to this project, Irish $M$. aethiopoides does have attributes that should enable the establishment of new parasitoid populations from as few as 10 parasitized weevils.

Firstly, extinction through the Allee effect predicted for small releases by Hopper \& Roush (1993) is not a factor since the parasitoid is thelytokous, which means all parasitoids and their progeny are female and there is no requirement for mate finding. Therefore, dispersal has no negative impact on the parasitoid gene pool or on reproduction as a single female can initiate a population in a new area.

Secondly, Irish $M$. aethiopoides has demonstrated repeatedly that it can multiply very rapidly in the field when conditions are favourable. For example, when 2500 parasitized weevils were released at the Lepperton nursery site in Taranaki on 19 December 2006, parasitism had reached 6\% after 7 weeks and by early June 2007 had reached $64 \%$. This was on a site with a high resident $S$. lepidus population (winter larvae $641 \pm 4 / \mathrm{m}^{2}$ ) and where mean air temperatures in January-March 2007 were $17.7^{\circ} \mathrm{C}$ (New Plymouth National Climate Base data). Possibly the ability to lay multiple eggs/host with most progeny surviving (Gerard et al. 2007) enables Irish M. aethiopoides to multiply more rapidly than $M$. hyperodae and the Moroccan $M$. aethiopoides biotype, which would have similar fecundity and search capability but are solitary endoparasitoids (Loan \& Holdaway 1961; Loan \& Lloyd 1974).

In a biocontrol distribution programme, the time required to undertake the extremely labour-intensive task of mass rearing 10,000 parasitized weevils must be balanced against the benefits of multiple smaller and earlier releases when hosts are most abundant, and the parasitoid can multiply rapidly through several generations during summer and commence dispersal in the field before larval diapause commences in autumn. Assuming a similar effective fecundity of 33 eggs/parasitoid as the Moroccan M. aethiopoides (Barlow \& Goldson 1993), and a 50\% mortality of parasitized hosts from predation, disease and other factors, 10 parasitoids released in December, when host weevils are newly emerged, fit and abundant, could produce over 5000 offspring by late February. So even though a single release of 10,000 parasitized weevils at a good site in February would have an excellent chance of success, releasing the same number of weevils parasitized at similar levels in batches of 10 over 1,000 sites from an earlier starting date is more likely to achieve widespread establishment, in spite of greater risk of failure of the individual releases.

This conclusion is similar to that of Memmott et al. (1998) who suggested that given a restriction in the number of available insects, a large number of smaller releases may increase the overall establishment, compared to a single large release. Based on experimental field studies, they considered the optimal release size for gorse thrips (Sericothrips staphylinus) being released in New Zealand for the biocontrol of gorse (Ulex europaeus L.) might be fewer than 100 thrips/release site. Similarly, single releases of 100 female parasitoids has been recommended as the optimal release strategy for the parasitoid Encarsi inaron (Walker) in a Californian programme to control the whitefly Siphoninus phillyreae (Haliday) after no differences were found between release rates of 100 or 1000 female parasitoids/site in rate of establishment, and impact on host peak and year-end densities (Bellows et al. 2006). Both these biocontrol agents reproduce sexually, and would be far more vulnerable than Irish $M$. aethiopoides to extinction through Allee effects. 
The giveaway approach overcomes two of the major impediments associated with the previous commercially-based $M$. hyperodae releases. With a cost of ca NZ\$15,000 each, the 1993-98 releases were concentrated in the wealthier dairy-farming districts, where either farmer groups or Regional Councils could accommodate the costs, and uptake was poor elsewhere, especially in the South Island (McNeill et al. 2002). In addition, while $M$. hyperodae dispersed rapidly in the warmer northern regions, it was slower to disperse in cooler regions of New Zealand, especially in Otago and Southland (Ferguson et al. 1997) where it was still absent in some districts 10 years following regional releases (Barratt et al. 2007). Partially this is because the rate of increase at release sites in Otago and Southland has been low (Ferguson et al. 1997), parasitism levels in dispersing adults is low compared to ground populations and because flight by L. bonariensis varies greatly year to year in response to climate (Goldson et al. 1999). Sitona lepidus behaves similarly, with few flight-capable adults when clover is abundant and summers cool and moist (Gerard \& Arnold 2002), and reduced parasitism in these individuals (Eden et al. 2008). Therefore natural dispersal of Irish M. aethiopoides via host flight activity will be highly dependant on both district and year and reliance on passive dispersal from two or three large release sites in regions where S. lepidus populations are in the relatively stable post-invasion state, would delay the widespread establishment of Irish M. aethiopoides.

Apart from the drought, the main constraint with the giveaway project was obtaining coverage in the non-dairying districts. In particular, there was a paucity of sheep and beef farmer-orientated events, such as monitor farm days, over the optimal time to carry out releases in summer. One option being investigated to reach these farmers is using commercial networks (e.g. fertiliser companies) to assist in the giveaway distribution. With the long term meteorological forecasts predicting more favourable weather in summer 2008/09, further giveaways are planned with focus on poorly-covered regions (Table 1), and sheep/beef farmers. Sampling is currently underway to assess the proportion of 2007 giveaways that have led to successful establishment.

\section{ACKNOWLEDGEMENTS}

The authors sincerely thank Susie James and our Waikato University summer students for their assistance in weevil collection and mass rearing, Chris Mercer and Bruce Cooper for help with the nursery sites in their regions, and the farmers who are hosting the sites. We thank the many DairyNZ consulting officers, Meat \& Wool NZ staff and farmers who distributed the giveaways and our Lincoln biocontrol colleagues for their advice, especially Mark McNeill and Stephen Goldson. The clover root weevil biocontrol programme is supported by New Zealand Foundation for Research, Science and Technology, DairyNZ and Meat \& Wool New Zealand.

\section{REFERENCES}

Barlow ND, Goldson SL 1993. A modelling analysis of the successful biological control of Sitona discoideus (Coleoptera: Curculionidae) by Microctonus aethiopoides (Hymenoptera: Braconidae) in New Zealand. Journal of Applied Ecology 30:165-178.

Barratt BIP, Ferguson CM, Bixley AS, Crook KE, Barton DM, Johnstone PD 2007. Field parasitism of nontarget weevil species (Coleoptera: Curculionidae) by the introduced biological control agent Microctonus aethiopoides Loan (Hymenoptera: Braconidae) over an altitude gradient. Environmental Entomology 36(4):826-839.

Bellows TS, Paine TD, Bezark LG, Ball J 2006. Optimizing natural enemy release rates, and associated pest population decline rates, for Encarsia inaron Walker (Hymenoptera: Aphelinidae) and Siphoninus phillyreae (Haliday) (Homoptera: Aleyrodidae). Biological Control 37(1):16-24.

Eden TM, Donald M, Gerard PJ 2008. The effect of parasitism on clover root weevil flight. New Zealand Plant Protection 61: 31-34. 
Eerens JPJ, Hardwick S, Gerard PJ, Willoughby BE 2005. Clover root weevil (Sitona lepidus) in New Zealand: the story so far. Proceedings of the New Zealand Grassland Association 67:19-22.

Ferguson CM, Evans AA, Barratt BIP, Phillips CB 1997. Establishment and dispersal of Microctonus hyperodae Loan (Hymenoptera: Braconidae) in Otago and Southland. Proceedings of the 50th New Zealand Plant Protection Conference. Pp. 41-46.

Ferguson CM, Phillips CB, Barton DM, McNeill MR, Townsend H, Vattala D 2008. Pupation depth of Microctonus spp. New Zealand Plant Protection 61: 389 (Abstract only).

Gerard PJ, Eden TM, Hardwick S, Mercer CF, Slay MS, Wilson DJ 2007. Initial establishment of the Irish strain of Microctonus aethiopoides in New Zealand. New Zealand Plant Protection 60: 203-208.

Gerard PJ, Arnold ED 2002. Influence of climate regime on clover root weevil adult survival and physiology. New Zealand Plant Protection 55: 241-245.

Goldson SL, Barker GM, Barratt BIP 1994. The establishment of an Argentine stem weevil parasitoid at its release sites. Proceedings of the 47th New Zealand Plant Protection Conference. Pp. 274-276.

Goldson SL, Proffitt JR, Baird DB 1999. Listronotus bonariensis (Coleoptera: Curculionidae) flight in Canterbury, New Zealand. Bulletin of Entomological Research 89: 423-431.

Hopper KR, Roush RT 1993. Mate finding, dispersal, number released, and the success of biological control introductions. Ecological Entomology 18: 321-331.

Loan CC, Holdaway FG 1961. Microctonus aethiops (Nees) auctt. and Perilitus rutilus (Nees) (Hymenoptera: Braconidae), European parasites of Sitona weevils (Coleoptera: Curculionidae). The Canadian Entomologist 93:1057-1079.

Loan CC, Lloyd DC 1974. Description and field biology of Microctonus hyperodae Loan n. sp. (Hymenoptera: Braconidae, Euphorinae), a parasite of Hyperodes bonariensis in South America (Coleoptera: Curculionidae). Entomophaga 19: 7-12.

McNeill MR, Goldson SL, Proffitt JR, Phillips CB, Addison PJ 2002. A description of the commercial rearing and distribution of Microctonus hyperodae (Hymenoptera: Braconidae) for biological control of Listronotus bonariensis (Kuschel) (Coleoptera: Curculionidae). Biological Control 24(2):167-175.

Memmott J, Fowler SV, Hill RL 1998. The effect of release size on the probability of establishment of biological control agents: gorse thrips (Sericothrips staphylinus) released against gorse (Ulex europaeus) in New Zealand. Biocontrol Science and Technology 8: 103-115.

Van Driesche RG. 1993. Methods for the field colonization of new biological control agents. In: Van Driesche RG, Bellows TSJ ed. Steps in Classical Arthropod Biological Control. Thomas Say Publications in Entomology, Lanham, MD, USA. Pp. 67-86. 